\title{
MORTE E PESSOA ENTRE OS KAXINAWÁ
}

Cecilia McCallum*

Em 1990, deu-se o seguinte diálogo entre Zé Augusto (A), líder de cantos e fitoterapeuta da região do rio Purus, Sueiro (s), antigo líder dos Kaxinawá do Jordão, e eu (C) ${ }^{1}$ :

C "O que faz a alma de uma pessoa quando chega no céu?

A Vive. Elas vivem lá sempre em festa, fazendo chidin, uman chani, nixpu pima, bunavai, kachanava [rituais]. Dizem que elas estão sempre se divertindo.

S Lá, diz-se que não têm mais dor de dente, não sofrem mais, não comem mais.

C Não comem?

A Dizem que elas estão sempre em festa, fazendo sai sai iki [ritual].

S Todo mundo animado. É aqui que a gente trabalha no sol quente e come. Sofre muito. Mas onde elas estão não é assim. É tão bom lá, dizem que elas não sofrem mais.

C E lá elas namoram?

S Dizem que não; isso é aqui. Eu acho que lá elas não fazem mais extravagância. Não têm dor de cabeça, não têm nada, não têm mais história. Não morrem mais."

Este artigo é essencialmente uma etnografia da morte e do processo de morrer, no passado e na atualidade, entre os Kaxinawá. A publicação, em 1986, do livro de Eduardo Viveiros de Castro, Araweté, deu início a uma nova fase dos estudos sobre a morte nas culturas das Terras Baixas da América do Sul2 ${ }^{2}$ Esse livro foi a primeira grande análise comparativa sobre o complexo conceitual do exocanibalismo dos grupos Tupi, contextualizado pela elaborada etnografia de uma de suas versões contemporâneas, a dos Araweté. O livro influenciou e inspirou os antropólogos da região não só na realização de estudos sobre a morte, como também sobre a categoria de pessoa, o gênero, a organização social, a atividade da guer- 
ra e a cosmologia ${ }^{3}$. A importância dessa obra está, principalmente, em ter proposto um quadro de referência analítico para uma antropologia social comparativa das sociedades da Amazônia, em que as cosmologias, ontologias e teorias indígenas sobre a pessoa ocupam uma posição central. A análise de um corpo de idéias e práticas referentes ao canibalismo funciona como ponto nuclear nesse quadro de referência, e por boas razões. Acompanhando a lógica indígena, Viveiros de Castro fez do ato de comer - mais precisamente dos atos de caçar, matar, cozinhar e comer - o fato central da análise sociológica. Posteriormente, esse quadro analítico veio a ser conhecido como "a economia simbólica da predação" (Viveiros de Castro 1992b; 1993; Rivière 1993).

Se este artigo ambiciona ter alguma significação maior que a de simples exposição (embora importante) de uma etnografia, é por contribuir para o recente debate acerca da "economia simbólica da predação", contribuição esta que contém uma perspectiva crítica ${ }^{4}$. Se Viveiros de Castro e seus alunos enfatizam a troca, da qual a predação é tanto um processochave quanto uma metáfora, esta análise procura realçar a importância do ciclo de "produção consumptiva", no qual a predação é apenas um processo vital, e a produção é outro. Tal ênfase não se deve, porém, a um mero capricho analítico. Este estudo está integrado a uma série de novas etnografias, recentemente produzidas na Grã-Bretanha, que tendem a sublinhar a importância da produção (Overing 1989; 1991; 1993; Gow 1989; 1991; McCallum 1989; 1990; Belaúnde 1992).

Para os Araweté e outros Tupi, o exocanibalismo - uma forma de predação - faz parte do processo de tornar-se pessoa. Os povos Pano, assim como os Kaxinawá estudados neste artigo, diferem significativamente dos "Tupi" por sua concepção de fabricação da pessoa, da capacidade de agir e criar [agency] dos deuses e do destino dos mortos ${ }^{5}$. Um indício claro dessa diferença é dado pelo endocanibalismo, que já foi um elemento central dos rituais funerários de muitos povos Pano (Erikson 1986; Dole 1974; Townsley 1988), que se situam, portanto, no pólo oposto ao dos Tupi, não só em termos do cardápio funerário, como também do ponto de vista sociológico. Por exemplo, enquanto a organização social dos Araweté é "fluida" e aparentemente não-estruturada, os Kaxinawá operam um sistema muito fechado, que combina exogamia de metades, casamento de primos cruzados bilaterais, uma terminologia de parentesco do tipo kariera e um sistema onomástico de gerações alternadas (Kensinger $1984 ;$ 1995) ${ }^{6}$. Focalizar o endocanibalismo funerário kaxinawá e as formas contemporâneas da morte e do processo de morrer pode revelar-se, portanto, um campo propício para dar continuidade à compa- 
ração analítica das relações entre cosmologia, escatologia, sociedade e pessoa nas Terras Baixas.

Os Kaxinawá pensam a morte como um processo que resulta da combinação de capacidades [agencies] possíveis de agentes humanos e celestiais. Este processo é marcado pelo gênero. As formas femininas e masculinas de morrer diferem em importantes aspectos. À primeira vista, essa diversidade é uma simples conseqüência das diferenças entre as formas como homens e mulheres vivem. Mas para os Kaxinawá, assim como para os Araweté ou os Krahó, essa diversidade faz parte de um conjunto mais amplo de idéias que dizem respeito à natureza do "outro", à afinidade e parentesco, à semelhança e diferença, à inimizade e amizade, à mortalidade e eternidade (McCallum 1994; Carneiro da Cunha 1978; Viveiros de Castro 1986; 1992a; Overing 1986). O gênero é um fator central em grande número de processos que giram em torno desses conceitos. Por exemplo, os Araweté concebem a humanidade viva como sendo "feminina", em contraposição aos deuses, que são "masculinos". Em todas as negociações entre os humanos e os deuses, o gênero é sempre uma preocupação básica. O mesmo ocorre entre os Kaxinawá, mas de maneira muito diferente, como se verá adiante.

Os Araweté vêem a vida humana como presentemente feminina, em seu caminho para a masculinidade futura, depois da morte. O canibalismo celestial é a chave dessa transformação. Os deuses matam as almas humanas, quando elas chegam aos céus, e consomem a carne e os ossos que as revestem, despojando-as das lembranças dos parentes vivos. Assim é que as almas se tornam eternas e os renascidos, eles próprios, se tornam deuses. Mas as relações sociais entre os vivos e esses novos mortos celestiais constituem um aspecto importante da vida cotidiana. Sua relação para com aqueles que "deixaram para trás" — os Araweté — é de afinidade externa. Eles visitam as aldeias dos vivos, comem o alimento e a bebida que lhes são oferecidos, interagem com os humanos por intermédio das vozes dos xamãs - e vão embora. Destituídos da memória dos afetos terrenos, os seus desejos orais satisfeitos, deixam os vivos em paz.

Os Kaxinawá costumavam tomar a si a responsabilidade de despojar da memória a carne e os ossos. O lugar da transformação do mortal em imortal era a terra, não o céu, o "interior", não o "exterior", e os agentes da transformação eram primordialmente humanos, não deuses. Mas os deuses também exerciam - e continuam a exercer - um papel causal fundamental no processo da morte. Este processo difere, de acordo com a passagem do morto pela vida e a conseqüente natureza de sua humanidade, especialmente nos aspectos relacionados com o gênero. Os 
Kaxinawá entendem a vida produtiva como fundada na relação produtiva entre capacidades [agencies] masculinas e femininas em interação recíproca e em interação com o exterior.

Para serem produtivos, os homens desenvolvem capacidades sociais de lidar com seres perigosos do exterior - a floresta, o sobrenatural, a cidade. A "capacidade masculina" [male agency], assim como a "capacidade feminina" [female agency], é antes ensinada do que inata (McCallum 1989; previsto b). Ela inscreve-se no corpo como aspecto intrínseco da individualidade específica que define sua condição de pessoa. Ao morrer, a capacidade de um homem para lidar com seres perigosos do mundo externo é submetida a um teste máximo, na medida em que enfrenta a hostilidade de certos espíritos e monstros. O momento da morte é assinalado pelo som da chegada de um espírito e de sua voz, dizendo: "Shui shui shui - eis a Arma do Estrangeiro... Terushka!". Só os homens ouvem isto no momento da morte, segundo me disseram. Ao viajarem para o céu, morada dos deuses, suas verdadeiras almas podem correr o perigo de ser extintas nas mãos dos espíritos-monstros (yuxibu) (Deshayes e Keifenheim 1982; Kensinger 1995). O fato de a ingestão da bebida alucinógena nixi pae ser uma forma quase exclusivamente masculina de adquirir conhecimento pode tanto ser a causa dessa difícil passagem da alma de um homem para o céu, quanto uma preparação para ela. Alternativamente, as almas dos homens podem também ser guiadas pelo Deus-Inka e seus seguidores, cunhados celestiais delas, através de um belo e largo caminho. Se alcançarem os céus, as almas podem ainda ser recebidas com demonstrações de hostilidade masculina pelos espíritos das armas, que lhes atiram flechas. Mas, excetuando-se os que são devorados durante a viagem, as verdadeiras almas são recebidas como deve ser feito com os parentes afins do sexo masculino - isto é, como "outros" transformados em parentes pelo consumo de alimentos vegetais. Seu destino é se tornarem Nai Yuxibu, "Deuses do Céu" (Lagrou 1991; Kensinger 1995). A morte dos homens é, portanto, mediada por relações de afinidade masculina que implicam duas possíveis conseqüências: a violência ou sua negação (fazer a paz). A morte dos homens reflete suas vidas, marcadas pela troca de hostilidades, ou sua superação, com outros seres masculinos.

A capacidade [agency] criativa das mulheres, por outro lado, realizase nos jardins e nas casas, onde o perigo é pouco e a coragem é uma capacidade secundária - só no ato de dar à luz é que as mulheres são consideradas mais corajosas que os homens. As relações das mulheres com os estrangeiros são geralmente mediadas por seus maridos e parentes homens. As mulheres transformam os produtos das atividades dos homens 
no mundo externo em pessoas, alimentos e coisas propriamente kaxinawá. Suas atividades em interação com as dos homens, constituem o "interior" da vida social kaxinawá (McCallum 1989). O processo de morte das mulheres reflete essa orientação. Se é possível dizer que os homens kaxinawá morrem por intermédio da afinidade masculina, as mulheres kaxinawá morrem por intermédio do parentesco. Novamente, é a expressão vocal dos espíritos, subitamente audível para uma pessoa agonizante, que distingue a morte de uma mulher da morte de um homem. Ao morrer, as mulheres ouvem apenas "shui shui shui", pronunciado pelos espíritos quando entram em seus corações. Então, seus próprios parentes mortos levam-nas para o céu, sem qualquer manifestação de hostilidade. No céu, elas também se tornam Deuses do Céu, e dissolvem sua alteridade por "tomarem um esposo Inka", como fazem os homens.

O contraste entre as formas masculina e feminina de morrer não é absoluto, pois o gênero é constituído em pessoas vivas, que diferem consideravelmente entre si, de acordo com as experiências e "conhecimentos" acumulados ao longo da vida (Kensinger 1992; 1995; McCallum 1996). Assim, uma mulher pode acumular, durante a vida, formas de conhecimento geralmente consideradas masculinas - como a sabedoria do olho - e as práticas funerárias acompanham essas diferenças (Kensinger 1995:233). O gênero deve ser entendido como um aspecto da humanidade que se constrói ao longo da infância e da vida adulta. As crianças kaxinawá são criadas para serem "seres humanos" verdadeiros, conceito expresso na sua autodenominação como "Huni Kuin". O gênero não é adscrito a priori, como decorrência do sexo biológico; ao contrário, vai sendo inscrito no corpo no decorrer do processo de transformação das crianças em verdadeiros seres humanos (McCallum 1989; 1996). Assim, a diferenciação do processo de morrer entre os gêneros depende da história particular de cada corpo. Embora eu tenha ouvido repetidas vezes dos Kaxinawá que homens e mulheres escutam sons diferentes e encontram espíritos diferentes em sua travessia para a vida póstuma, acredito, hoje, que essas afirmações fazem parte do processo de constituição das diferenças de gênero. Não são produtos de uma distinção conceitual absoluta entre homens e mulheres, ou entre formas masculinas e femininas de morrer. Vejo agora que, ao contrastar a maneira como homens e mulheres morrem, estamos lidando com simbolizações do gênero, estreitamente relacionadas, mas não de todo limitadas, ao gênero mutável que é inerente a corpos vivos e em atividade.

Por si mesma, a diferença entre os processos masculino e feminino de morrer não é muito importante. Permite-nos ver, porém, que os modos 
de conceber as relações entre mesmo e outro, assim como os processos de ser e de tornar-se, fundamentam-se no gênero tal como se passa entre os Araweté. Pois se os homens são representados como o lado "exterior" da interioridade [inside's outsiders] — caçadores, guerreiros, genros vivendo uxorilocalmente e líderes da aldeia —, as mulheres são o lado interior da exterioridade [outside's insiders] — que ocupam o centro da vida da aldeia, preparam e servem os alimentos, os quais, uma vez consumidos, geram e consolidam o parentesco, nutrem e criam os bebês em seu próprio corpo, semeiam e colhem as plantas alimentícias e incutem nas pessoas e nas coisas o "grafismo verdadeiro" (Kene Kuin), determinando e efetuando, por isso mesmo, sua transformação naqueles que são os verdadeiramente humanos — os Huni Kuin. Suas atividades criam incessantemente o interior, o espaço de viver. Mas, paradoxalmente, é o parentesco com os mortos que realiza sua passagem para o outro mundo.

Este artigo é apenas uma exploração parcial dos temas propostos nesta introdução. Muitos aspectos das cosmologias contemporâneas precisam ainda ser compreendidos, outras questões necessitam ser postas aos Kaxinawá, antes que seja possível confirmar as interpretações aqui sugeridas. Contudo, acredito que em suas linhas essenciais, a análise se sustenta. Passemos então, sem mais delongas, às questões fundamentais.

\section{Corpo e alma}

Há duas yuxin ("almas") principais". A alma do olho, bedu yuxin — também chamada de verdadeira alma, yuxin kuin —, é visível no brilho do olho. A alma do corpo, yuda yuxin, é um aspecto da substância do corpo. Ela o envolve como uma pele exterior e é percebida como uma aura, uma luminosidade, "a simples presença física" de uma pessoa (Kensinger 1991; 1995). Está ligada à sombra da pessoa (yuda baka ou yuda bake) e ao seu reflexo. Existe ainda um grande número de outras yuxin, menores. O espírito do sonho - nama yuxin - divaga pela noite e encontra-se com outros espíritos. Após a morte, vagueia até o ponto mais alto da casa. Depois, afasta-se e fixa morada nas copas das árvores mais altas, de onde pende a secreção nasal derivada do pranto dos parentes vivos, e que constitui o yuxin dexu, "espírito do muco", encontrado pelos caçadores em suas incursões na floresta (Kensinger 1995). Substâncias que se desprendem do corpo são yuxin - urina, fezes, dentes e saliva, mas não cabelos, sangue, sêmen e outros fluidos corporais. Algumas pessoas consideram as emoções e as qualidades morais como yuxin; contudo as opiniões diver- 
gem a respeito dessas almas menores. Um homem me disse que três espíritos moram dentro do olho e constituem a alma do olho: os espíritos da fraqueza, da felicidade e do furto. Quando nossos parentes morrem, ficamos muito tristes, porque nosso espírito da felicidade foi embora. Um outro, "crente", que vivera algum tempo, quando criança, entre não-índios locais, afirmou que nossos corações podem ser possuídos por almas boas e más. Quando o yuxin pepa ("espírito bom") penetra o coração, a pessoa é feliz, bondosa e tem amor pelos filhos. Quando o "espírito mau" (yuxin chakabu) toma conta, a pessoa fica mal-humorada e grita com os parentes. O yuxin chakabu é o puro mal, também chamado de Cão ou Satanás pelos não-índios. Segundo meu informante, o "espírito bom" também é chamado de Espírito Santo. Ele me contou que, embora tivesse aceito a Jesus Cristo, às vezes ficava irado e se comportava mal. No passado, tinha assassinado muitas pessoas, mas abandonara essas ações ao se converter. Entretanto, acrescentou ele, quando estava possuído pelo espírito mau, não lhe custava muito matar uma pessoa. Permanecer bom é, então, um permanente processo de repelir o espírito maligno. Os "crentes", que existem entre os Kaxinawá, mas não são maioria, fazem regularmente longos encontros de oração como parte dessa luta.

Independentemente desses detalhes sobre o conceito de yuxin, em relação à pessoa, todos os Kaxinawá parecem acreditar no princípio de que os seres humanos têm duas almas principais - a alma do olho (ou verdadeira alma) e a alma do corpo. Esta última, vincula-se intimamente ao corpo e, quando o deixa, causa doenças graves e até a morte ${ }^{8}$. Associa-se ao estado de vigília, ao estado de consciência do corpo, ao conhecimento e à acumulação progressiva da memória. Diferentes partes do corpo acumulam conhecimentos e habilidades específicas no decurso da vida e essa condição epistemológica de dinamismo está intimamente ligada à alma do corpo (Kensinger 1995; McCallum 1996). Muitas coisas que um adulto pleno sabe fazer - tais como falar, aprender, ter relações sexuais, exercer atividades produtivas, comer - se tornam aspectos da alma do corpo. Sendo assim, a própria criação de gênero também está estreitamente vinculada à formação da alma. Os mais velhos possuem yuda yuxin particularmente poderosas. As almas dos corpos dos xamãs, dos curandeiros e dos feiticeiros são especialmente temíveis ${ }^{9}$. Como em outros grupos Pano, como os Yaminawá, por exemplo, só é possível compreender as noções de pessoa em um contexto epistemológico (Townsley 1988). Uma maneira de fazê-lo é entender a memória como algo que se entranha progressivamente no corpo ao longo da vida. O conhecimento, as habilidades práticas, as capacidades intelectuais e a consciência em 
vigília, acumulados durante a vida, tornam-se uma verdadeira "segunda natureza" para os Kaxinawá. Desse modo, a yuda yuxin é extremamente individual. Pessoas diferentes possuem almas do corpo mais ou menos poderosas, dependendo de suas respectivas personalidades e capacidades. Portanto, a individualidade de uma pessoa incorpora-se em boa parte à alma do corpo, que é produzida por histórias de vida particulares e por relações específicas com outras pessoas. Sem dúvida, não só a diferença se integra à alma do corpo; a semelhança também o faz. Nesse sentido, todos os Kaxinawá têm almas do corpo semelhantes, pois boa parte do que conhecem e fazem é comum a todos; assim, também, as almas dos corpos de mulheres e homens são diferentes, pois é diferente o que mulheres e homens fazem.

O conhecimento vinculado ao corpo é adquirido, em parte, junto às plantas, aos "remédios" e às criaturas (especialmente, as cobras), que são manifestações terrenas dos seres primordiais - yuxin e yuxibu poderosos ("monstros", "deuses"), eternamente existentes nos tempos míticos. Os processos rituais e os procedimentos cotidianos mediante os quais os parentes mais velhos e os afins instilam esses conhecimentos nos corpos dos jovens são diferentes para meninos e meninas. Mas o processo de ensino, em ambos os casos, obedece a uma mesma lógica - forças externas são vinculadas à pessoa. Contudo, os homens - e suas almas do corpo - adquirem uma experiência (conhecimento) consideravelmente maior por intermédio do contato violento com o exterior durante a vida. Eles lidam com inimigos e espíritos da floresta, matam animais para comer, derrubam árvores gigantescas. O contato visual com o exterior também é obtido pela ingestão da bebida alucinógena nixi pae, que é geralmente reservada aos homens. Por meio dessa bebida, pode-se ver o futuro e, com isso, desenvolver "a sabedoria do olho" (Kensinger 1973; 1995).

A alma do corpo está, portanto, ligada ao tempo progressivo, à mudança, ao crescimento e ao declínio. A alma do corpo de um Kaxinawá constitui-se em grande parte pela intervenção humana no corpo. Inversamente, a verdadeira alma (ou alma do olho) está associada à alma imortal criada por Deus (Diusun, derivada de Deus, em português, ou de Dios, em espanhol). As criaturas vivas manifestam sua alma do olho no brilho dos olhos desde o momento do nascimento. A vida, doada por Deus, só é possível por causa de sua presença. Alguns informantes comparam Diusun com a divindade Inka Kuin, o deus criador que governa os céus. Na morte, a verdadeira alma tenta viajar até o seu reino, onde se diz que ela toma um cônjuge inka e passa a viver eternamente nas aldeias celestes perfeitas do povo inka ${ }^{10}$. A pobre alma do corpo, ao contrário, não 
desfruta desse paraíso após a morte. Forçada a desligar-se do corpo, ela se apega ao túmulo, onde se demora, sob uma forma hedionda, perseguindo, assustando e ocasionalmente infligindo doenças aos parentes vivos, se eles não tomam precauções. Os parentes têm pena e medo da alma, até que ela finalmente deixa o túmulo e parte para a terra de onde veio, seu lugar de nascimento. Então, a alma do corpo escapa voando para a região da floresta e da nascente dos rios, onde teve origem, ao passo que a verdadeira alma sobe para os céus. São essas as questões que focalizo a seguir.

\section{O fim do corpo e o destino das almas}

Oito décadas antes que eu escrevesse essas palavras, um jovem kaxinawá descreveu o processo de morrer para um pesquisador brasileiro da seguinte maneira:

“Os Huni Kuin sempre sofrem de uma doença quando morrem. Eles morrem porque alguém 'pôs remédio neles' (Dau vanbu imiski, juni kuin mavaidan). Eles pegam todo tipo de doenças. Os que vão morrer, não comem nada e só os que vão ficar bons comem. Os parentes preparam remédios (dau) para curá-los. Pegam o remédio, esquentam a água e lavam o doente. Quando a pessoa desmaia, os parentes choram. Eles sempre tentam curar os doentes (xuxa va-). Todos os parentes se reúnem. Quando o coração pára, eles sabem que a morte chegou“ (Capistrano de Abreu 1941:140-141).

Esta citação nos diz, entre outras coisas, que a intervenção humana dá início ao processo de morrer. Feiticeiros e envenenadores aplicam substâncias diretamente sobre o corpo, ou dentro do corpo, para matar. Hoje em dia, poucos são os que atribuem abertamente as doenças à ação de outras pessoas conhecidas, como fez o informante de Capistrano de Abreu. A doença costuma vir "de fora", como "doença de branco"11. Mas o processo de cura, com seu método peculiar de "ficar de luto" antes que a morte aconteça, continua a ser praticado, visando contrabalançar uma segunda e definitiva forma de intervenção no processo de morrer - a dos espíritos do morto, dos deuses do céu e dos demônios.

Nas descrições da doença e da morte, citadas a seguir, baseio-me em experiências pessoais na região do Alto Purus, entre 1984 e 1985. Tive a ocasião de assistir, pessoalmente, à morte e ao sepultamento de dois adultos, sobre os quais baseio meu relato ${ }^{12}$. 
Quando uma pessoa muito doente desmaia, as mulheres da casa lançam um terrível grito de dor. Gente acorre de toda parte da aldeia para assistir à morte. Dizem que a pessoa já morreu (ma mavaxuki); no caminho, apanha-se uma vela para acender em cima do corpo do moribundo. Sua casa logo se enche de gente; todos permanecem de pé, guardando uma certa distância da rede de dormir do doente, em torno da qual ficam os parentes mais próximos. O mosquiteiro é levantado para que todos possam ver melhor. Os parentes sentam-se à cabeceira do doente, lamentando-se em voz alta de uma forma ritualizada e implorando ao seu espírito que não parta. Esse lamento formal, mas muito triste, e que começa antes mesmo da partida final do espírito, é uma tentativa de cura. As velas iluminam o corpo do moribundo sobre o qual se esparge um pouco de sal. Quando a pessoa recobra a consciência, o lamento se detém, mas se ocorre um novo desfalecimento, as mulheres elevam a voz e o catarro começa a escorrer-lhes das faces. Elas gritam aos ouvidos do parente: "Não vá, fique conosco, não nos deixe! Tia, tio, filho [etc.], você está me ouvindo? Ouça minha voz! Não vá embora!"

Um líder de cantos poderia entoar preces especiais destinadas a trazer de volta o espírito do olho que fugiu, ou, se não houver mais esperanças, orações que ajudem a apressar sua viagem para o outro mundo (McCallum 1996). Quando o coração pára de bater e o espírito escapou, deita-se o corpo no chão e recomeçam as lamentações. Esse luto ritualizado é chamado de nui kaxadin, algo como "sessão de pranto e de sentir a perda". Os parentes mais próximos devem permanecer até a aurora, quando os olhos estão vermelhos e as vozes enrouqueceram. De vez em quando soltam gritos pungentes de dor. Lágrimas e secreções escorrem por suas faces ${ }^{13}$. Pouco depois, voltam a sentar-se perto do corpo. Os parentes que chegaram atrasados executam, ao entrar, a dança do luto. Homens e mulheres choram de maneira diferente. As mulheres dançam por algum tempo, dando passos para a frente e para trás, as palmas das mãos viradas para cima, movendo-se no ritmo de seus soluços. Os homens dançam em círculo em torno do cadáver, obedecendo ao ritmo de seu choro, segurando uma espingarda de caça com a boca virada para a frente. De cabeça baixa, cobrem o rosto com o antebraço. Quando a dança termina, os homens reúnem-se aos demais parentes em volta do cadáver. Então, homens e mulheres sentam-se para chorar juntos.

Logo depois, os parentes ou os filhos do morto vestem o corpo com suas melhores roupas. Dão busca em todos os cantos da casa para encontrar outros pertences do morto, os quais são colocados ao redor do cadáver. Se o defunto é uma mulher, as parentas mais velhas coordenam os 
preparativos. Os participantes do funeral continuam as lamentações até a aurora, com breves pausas durante as quais conversam normalmente entre si. Lanternas e velas permanecem acesas a noite toda e não são apagadas mesmo depois que o sol nasceu.

Durante o velório, os participantes podem posicionar-se atrás da fileira dos parentes do morto, conversando e, às vezes, rindo. Ninguém se sente muito à vontade para dormir nessa noite. $\mathrm{O}$ ambiente fica muito carregado por causa do medo da alma do defunto. A aldeia permanece iluminada a noite inteira para prevenir a chegada de alguma visita indesejável.

Pela manhã, todos retornam à casa do morto (ou dirigem-se para o local do velório). Orações e hinos são liderados por um dos "crentes". À ordem de "Oremos!", todos abaixam a cabeça e fecham os olhos. Se um líder de cantos mais idoso decide cantar a "canção de despedir a Alma", os participantes sentem-se mais à vontade. A única vez que presenciei isso, eu vi que as crianças menores eram retiradas nesse momento. O canto pertence ao gênero chamado de pakadin, que pode ser traduzido como "reza". Antônio Pinheiro assim descreveu o que se passa então:

"Com a pakadin, a yuda yuxin (ou yuda baka) é deixada para trás durante o processo de despedida. Todos os tipos de alma são mandados embora - urina, saliva. Elas nunca vão embora, a alma das fezes nunca vai embora. Só a verdadeira alma sempre vai embora, para o lugar de Deus, o lugar de Inka. A canção que se canta para um homem - 'Despedindo seu Espírito' — diz o seguinte: 'Siga seu caminho, não volte, coloque suas vestes amarelas, use-as quando estiver indo, não volte nunca mais. Parte de uma vez, não volte atrás'"14.

Desse modo, a alma do corpo e as outras almas menores não se retiram, mesmo quando são mandadas embora. Só a verdadeira alma toma o rumo do seu destino nos céus. Uma estudiosa dos Kaxinawá escreve que era costume cantar essa canção durante o processo endocanibalista, no momento em que os ossos do morto eram queimados antes da trituração (Lagrou 1991:118). As vestes amarelas fazem referência aos ornamentos do Inka (Lagrou 1991:118), primeiro sinal da iminente transformação do morto em um Inka.

As verdadeiras almas tornam-se nai yuxibu ("deuses do céu") quando são apropriadamente cantadas (Lagrou 1991). Caso contrário, como relata a autora, transformam-se em ni yuxibu ("espíritos das florestas"). Outra versão afirma que, enquanto as verdadeiras almas se transformam 
em deuses do céu, as almas do corpo tornam-se espíritos da floresta (Kensinger 1995). Os informantes de Lagrou afirmaram também que os xamãs se transformam em cobras ou jaguares após a morte.

O enterro é realizado logo que terminam as orações. Prefere-se levar o corpo para uma povoação que tenha cemitério. No caso de um povoamento recente, que não dispõe de um campo funerário, o cortejo prefere viajar por algumas horas até outra comunidade a inaugurar um cemitério local. Os cemitérios costumam ser localizados em um trecho da floresta distante dos caminhos mais freqüentemente utilizados. O corpo é enrolado em sua própria rede, suspenso por uma vara e carregado até a cova previamente preparada por um grupo de rapazes. Se a viagem é demorada, os parentes próximos irrompem de vez em quando em prantos, mas ninguém se demora rezando ou chorando no cemitério. Os jovens brincam entre si enquanto trabalham sob a orientação de um homem mais velho. Finalmente, o corpo é deitado na cova, sobre tábuas feitas de madeira de palmeira (quando não se consegue um caixão), cercado por algumas de suas posses. A cabeça é colocada na direção da "nascente do rio"15. As outras posses são queimadas ou jogadas no rio ou na floresta à beira da aldeia. Várias tábuas são trançadas em cunha por sobre o corpo e outras no sentido do comprimento para formar uma espécie de "teto". Depois, o coveiro sai de dentro da sepultura. Nesse momento, o ambiente torna-se mais grave; todos se aproximam, carregando punhados de terra que são jogados sobre as tábuas; depois, lavam as mãos com a água trazida dentro de uma panela e o cortejo se dispersa, deixando-se aos jovens a tarefa de terminar o trabalho. Quando o túmulo fica pronto, coloca-se em cima uma lâmpada de querosene acesa. Mais tarde, uma cruz é erguida aos pés da tumba (na direção da "foz do rio"), deixando-se em cima um objeto muito valioso do morto - uma espingarda ou facão, no caso de um menino ou de um homem, algumas panelas, no caso de uma mulher.

Deshayes e Keifenheim presenciaram a morte de Pudicho Torres, um importante líder masculino em Balta, no rio Curanja, pai do atual chefe Grompes ${ }^{16}$. No momento em que Pudicho morreu, as paredes de sua casa foram destruídas a machadadas. Suponho que isso tenha sido feito para abrir caminho para a saída da alma. (As duas mortes de adultos que presenciei ocorreram em casas sem paredes.) Quando a alma do chefe chegou ao céu, um relâmpago anunciou aos vivos que os espíritos das armas (pia yuxin) estavam atirando flechas contra ele, o que significava que sua viagem tinha sido completada com êxito. Sinais celestiais desse tipo são por vezes substituídos ou acompanhados, na terra, por uma 
salva de tiros e o espocar de fogos de artifício uma semana depois da morte - sinal de que a alma chegou ao fim do processo de partir.

De acordo com Deshayes e Keifenheim (1982), nui kaxadin (o ritual de chorar e dançar) destina-se a acompanhar a yuxin kuin rio abaixo até a base do mundo, a "raiz do céu". Lá, a xanen tapiti - uma escadaria gigante encostada em uma enorme árvore - leva até o céu ${ }^{17}$. Sob a influência da cultura euroamericana, essa concepção parece vir-se modificando gradualmente, mas não houve ainda uma mudança radical. As novas idéias, como aquelas oferecidas pelas diversas formas de cristianismo com que se deparam os Kaxinawá, têm sofrido modificações para se adaptarem às crenças nativas mais arraigadas. Meus informantes disseram, por exemplo, que o destino da alma do olho é o céu (muito raramente o inferno). O céu corresponde a nai e o inferno ao mundo subterrâneo que é o "puro rio" (jene). Informantes disseram ainda que a raiz do céu está localizada no Ceará, de onde provinham muitos colonos não-índios da região. Diz-se, também, que as almas mortas viajam até o arco-íris, sintan, chamado de caminho do Estrangeiro, Navan bai, ou caminho de Inka, Inka bai, para os céus. Algumas pessoas descrevem o Inka bai como uma senda larga e limpa que atravessa a floresta. Antônio Pinheiro, um Kaxinawá brasileiro, que viveu muitos anos na região do rio Curanja, fez uma descrição do Inka bai para Lagrou. Segundo ele, é um caminho por terra, enfeitado com plumas azuis, vermelhas, pretas e brancas. Na "Canção de Despedir a Alma", o Inka bai é descrito como um caminho coberto de desenhos formados por penas de muitas espécies de pássaros. "O morto vê como o lugar é bonito", disse-me Antônio Pinheiro. Os "Belos Inkas" descem o caminho, vestidos com cocares de plumas azuis e com cushmas (uma espécie de poncho) cobertos por desenhos, tocando flauta, trombeta e tambores. O mesmo informante relatou-me que os homens do Inka vêm acompanhar a alma do morto, dançando chidin, um estilo de dança associado a um complexo de ritos, importante e peculiar, que serve, entre outras coisas, para a iniciação dos chefes do sexo masculino (McCallum 1989). Quando carregam as almas dos homens, elas também dançam chidin.

Os acompanhantes do Inka exprimem e condensam a relação de afinidade masculina que liga os homens mortos à vida póstuma. Eles são os cunhados celestiais do morto. Este deverá desposar uma das irmãs dos Inkas na aldeia do céu, e assim transformar-se em um Deus do Céu. Por causa do chidin, a transformação do homem vivente em um Nai yuxin traz ainda uma outra associação, a da transformação de um homem comum em um homem investido de autoridade e liderança masculina. 
Nem todas as mortes obedecem necessariamente a esses princípios, como afirmei anteriormente. A alma pode ser devorada por espíritosmonstros, por exemplo. A experiência de um homem que esteve à beira da morte implicou, por exemplo, ser arrastado para um buraco aberto no chão pelos espíritos; outro foi levado em um carro por brasileiros para visitar seus ancestrais mortos. Em suma, a estrada para o além-mundo é variável, dependendo do indivíduo. Mas sempre acaba acontecendo um deslocamento vertical, mesmo quando a viagem começa atravessando a floresta ou descendo o rio. Ouvi de alguns informantes que, quando um homem está agonizando, ele vê o teto de sua casa (xubu) transformar-se em um grande declive, um mava. Como o verbo que significa "morrer" é mava-, o processo de morrer pode estar associado a um eixo espacial vertical. Igualmente importante é a idéia de movimento ao longo desse eixo. O verbo "ir" ( $k a-$ ) pode ser usado como eufemismo para "morrer". Às vezes, a partida da alma do olho é descrita como se fosse o vôo de um besouro ou de um pássaro. Ela poderia ser arrastada por um nai yuxibu, como Ixmi, o Urubu-Rei (Lagrou 1991). O próprio termo bai (caminho) sugere movimento; significa também a correnteza de um rio e, na forma verbal, ir visitar.

Não deixa de ser significativo que, entre os Kaxinawá, as saídas mais freqüentes das mulheres sejam para visitar parentes em outras casas, aldeias ou povoações. O processo de morrer, entre as mulheres, é controlado, sobretudo, pelo restabelecimento dos laços com parentes falecidos. Os mortos recentes são particularmente atraídos pelas mulheres da família. Quando alguém morre, elas se tornam suscetíveis a receber visitas do morto em sonhos, o que lhes causa grande tristeza e saudade, além de doenças. Porém, a morte das mulheres assemelha-se à dos homens. Quando morrem, suas almas também viajam pelo Caminho do Estrangeiro ou Caminho do Inka. Uma mulher me falou desse arco-íris, a partir de sua experiência de ter estado perto da morte, como sendo "muito suave, como uma estrada feita de ladrilhos"18. Antônio Pinheiro explicou que os parentes da mulher também chegam ao velório dançando chidin, arrastando os pés e cantando "Heeeeeeee" (que é o passo da mulher no chidin). Seus parentes mais próximos - o irmão mais velho, a mãe apelam à mulher, dizendo, "Vamos embora agora". Portanto, também no caso das mulheres, a progressão vertical da morta acompanha o ritmo da iniciação dos líderes do sexo masculino, como se o mero contato com o Além - e uma provável transformação em Deus do Céu - tivesse o efeito de masculinizar a alma da morta, ao elevá-la. Especulações à parte, a futura integração no mundo dos Inkas também se realiza por meio do 
casamento com um deles. Mais uma vez, um eufemismo mais antigo para "morrer", no idioma kaxinawá, é "Inka benewa-" (casar com um marido Inka) ou Inka ainwa- (desposar uma mulher Inka). Qualquer que seja a relação inicial com a alma do morto - de afinidade masculina ou de parentesco - , uma morte suave e bem-sucedida implica sempre uma integração equilibrada dos dois gêneros por meio da união conjugal: uma relação de afinidade celestial que, no entanto, não tem nenhuma das conseqüências produtivas ou reprodutivas de um casamento terreno. As almas dos mortos nem trabalham nem têm relações sexuais, mas passam todo o tempo em rituais, dentre eles o chidin.

O chidin também funciona, em casos especiais, como um rito fúnebre. Constituindo, em sua essência, um meio de reiterar e refazer toda a criação do mundo, o ritual é implementado em momentos de crise da comunidade ou após um acontecimento particularmente perturbador, como a morte de um líder importante ${ }^{19}$. Exemplo disso foi a realização de um chidin após a morte de Pudicho Torres, líder de Balta (Deshayes e Keifenheim 1982). Outro chidin ocorreu em 1985, em Recreio, após a morte de Luísa, líder feminina da aldeia, e de seu tio-pai, Sampaio, importante fitoterapeuta e líder de cantos. Em todos esses casos, o complexo ritual encerrou o ciclo funerário.

\section{O corpo após a morte}

Enquanto a alma do olho segue seu caminho ascendente ou descendente para o além-mundo, a alma do corpo permanece ligada ao local da morte. O velório serve, ao mesmo tempo, para acalmar a alma do corpo e para assegurar seu desligamento do corpo, separação esta que é relativamente menos problemática para a alma do olho. A alma do corpo é um perigo para todos os que moram perto do local onde ocorreu a morte, e não apenas para os parentes mais próximos, como acontece com a alma do olho. A primeira representa o aspecto mais poderoso e assustador de uma pessoa falecida. No caso de Pudicho Torres, sua alma pairou sobre a aldeia durante vários dias, na forma de uma nuvem densa e escura (Deshayes e Keifenheim 1982). No passado, o endocanibalismo é que efetuava o desligamento da alma (ver descrição adiante). Os Yaminawá dizem que a alma do corpo se agarra à carne em putrefação até que todo o cheiro desapareça e a decomposição se complete. Para os Kaxinawá, o risco que se prolonga durante esse período pode ser amenizado se uma lanterna de querosene for deixada queimando sobre a tumba e uma ou- 
tra for mantida, à noite, dentro dos quartos. No prazo de uma semana, a alma vai embora, retornando à terra onde nasceu a pessoa falecida. Ao voar para esse lugar, ela emite um som: Saiiiin. Assim, a alma do corpo retorna à floresta que agora cobre a aldeia abandonada onde ela aparecera pela primeira vez. Ali, ela se torna um espírito da floresta, ni yuxin. Sua partida repentina é definitiva.

Outro método para assegurar a separação entre a alma e o corpo é destruir os pertences da pessoa, mabu. As posses do morto devem ser jogadas fora ou destruídas. Será por que as almas do corpo "se recordam" de suas coisas terrenas, são atraídas por elas e por isso voltam à aldeia? Não tenho certeza. Mas a alma do corpo parece realmente tornar-se anônima e despojada de memória depois de partir, enquanto a verdadeira alma, que alcança o céu - e se transforma em um deus celeste (nai yuxi$b u)$ - , continua a lembrar daqueles que a amaram durante a vida. Ela se lembra, principalmente, de suas próprias parentas e essa recordação se expressa quando volta para buscar as almas verdadeiras das mulheres da família.

A lembrança e a emoção que as posses do morto provocam nos parentes vivos são muito perigosas. Os vivos não querem ser lembrados daquele que perderam. É mais prudente que as pessoas influenciáveis evitem olhar para fotografias (yuxin) do morto, pois isso poderia lhes causar um acesso de choro. Há um vínculo muito estreito entre o conceito de yuxin e a emoção, como vimos acima. Algumas pessoas consideram as emoções e as qualidades morais - tristeza, fraqueza, felicidade - como espíritos que habitam o corpo. Assim, há um duplo processo de esquecimento: tanto as almas quanto seus parentes vivos devem abrir mão de suas lembranças. Evita-se pronunciar o nome de batismo do morto em voz alta. Quando indispensável, o nome deve ser precedido pela palavra "finado".

Uma pessoa pode consumir-se em dor e saudade. Por meio do luto (nui kaxadin), os parentes próximos enfatizam seus laços com o morto. Na verdade, os parentes próximos falecidos jamais são esquecidos: sua memória é indicada pelo termo manu-, que faz referência à saudade e ao perigoso sentimento de perda. Sentir saudade em excesso provoca momentos de grande sofrimento, um sentimento de completa solidão e abandono. Quanto mais uma pessoa se lembra de quem perdeu, mais deseja reunir-se ao morto. Pessoas assim, deprimidas e taciturnas, ficam doentes facilmente. Uma forma eufêmica de referir-se a "estar doente" é mavakatsi ikiki, "ele ou ela deseja morrer". Igualmente, um eufemismo para morte pode ser traduzido por "seu pensamento/memória já não está leve" (ana xinan xankanmaki). 
Os espíritos das excrescências corporais de uma pessoa também ficam rondando o povoado onde ela morou, assim como as almas das secreções nasais ficam agarradas às árvores. Esses espíritos não são particularmente perigosos. As almas da urina agacham-se à noite, pelos cantos dos quartos de dormir onde as pessoas urinam de madrugada entre as frestas do piso de paxiúba Matreiramente, elas sacodem as redes ou balançam a choupana, provocando insônia. Um "crente" me disse que essas almas só trazem perigo para os que "não aceitaram a Jesus Cristo". Também os espíritos das fezes podem perturbar as pessoas quando elas se chegam à beira da floresta para defecar.

As almas dos mortos não são especialmente malvistas em uma forma despersonalizada. As visitas anuais ao cemitério no Dia dos Mortos do catolicismo (2 de novembro) servem a vários propósitos: limpar os túmulos, garantir que as almas não venham a perturbar os vivos, angariar sua ajuda para o próximo ano. Acender velas e fixá-las nas cruzes de madeira é uma forma de pedir ajuda.

No dia 2 de novembro de 1984, fomos limpar os túmulos de Sampaio e Luísa. O pai dela, Zé Augusto, soluçava conforme o estilo nui kaxadin, enquanto se ocupava de arrancar as ervas daninhas e amontoar a terra. O filho adolescente também ajudava, substituindo cuidadosamente os objetos que haviam sido deixados na tumba de sua mãe (uma caçarola, uma cafeteira, uma caneca esmaltada, pratos, colheres e um pequeno balde de plástico). $\mathrm{O}$ irmão de Luísa dava uma ajuda, chorando silenciosamente. O filho e o genro de Sampaio limpavam seu túmulo, enquanto outras pessoas cuidavam das sepulturas dos cinco bebês mortos no ano anterior — "os anjinhos", como observou o irmão de Luísa. Este rezava em voz alta enquanto acendia as velas e fixava-as sobre as cruzes, dirigindo-se primeiro à sua irmã falecida, depois ao tio. Fazia-lhes elogios e pedia que o ajudassem no ano vindouro. O cunhado, Pancho, também acendeu velas e, na qualidade de missionário crente, leu alguns trechos do Novo Testamento. Depois disso, tiramos algumas fotos ao lado dos túmulos e fomos embora, deixando atrás o pai de Luísa que soluçava alto. Horas mais tarde, um soluço ou outro podia ainda ser ouvido. É que haviam lhe dado uns goles de cachaça.

As pessoas podem chorar por uma alma, no estilo tradicional, anos depois da morte, quando uma lembrança vem à mente. Por ocasião de minha partida "final" de Recreio, o pai de Luísa rompeu num choro ritualístico porque (assim me disse seu filho mais tarde) eu era muito ligada à sua finada filha. Durante uma visita posterior, ele me abraçou e chorou 
pelo mesmo motivo, deixando constrangidos todos que estavam na casa. Sua mulher, Alcina, explicou-me que "Mia juinbaidebuniken, manui, kaxamiski" ("Toda vez que você vem nos visitar, ele chora porque sente saudades"). O luto, nui kaxadin, não é, portanto, uma ação unívoca, destinada apenas a conter ou despedir uma alma. É também uma manifestação dessa alma junto ou dentro dos que a pranteiam, assinalada por fortes sentimentos de tristeza e perda. Chorar é tanto uma maneira de amenizar os sentimentos quanto de expressá-los. Ao mesmo tempo saúda e reconhece a alma, e manda-a embora. Por isso, chora-se tanto a volta de um parente após longa ausência, quanto sua partida. Na última vez que o visitei, o pai de Luísa não chorou; deu um sorriso largo e me perguntou gentilmente: "Ana kaxayamapa?" ("Posso não chorar outra vez?").

\section{Consumindo parentes}

O endocanibalismo foi praticado nas comunidades peruanas até o início dos anos 50. No Brasil, essa prática foi abandonada um pouco mais cedo, mas com toda certeza era realizada até, pelo menos, a primeira ou segunda década deste século (Sombra 1913; Carvalho 1931). A forma do canibalismo variava: o corpo podia ser fervido ou assado. Não era uma prática universal e se limitava a determinados parentes adultos, especialmente os mais importantes, homens e mulheres de mais idade (Kensinger 1995). Os corpos de feiticeiros conhecidos eram queimados, enquanto os corpos de pessoas sem parentes próximos eram enterrados. Posteriormente, os ossos podiam ser exumados por parentes próximos, assados, moídos e consumidos (Lagrou 1991). Antônio Pinheiro descreveu-me o endocanibalismo de seus pais e avós da seguinte maneira:

\footnotetext{
"Os corpos foram cozidos e a carne ingerida. Os restos foram enterrados no centro da casa comunal e acendeu-se uma fogueira em cima do túmulo. Mais tarde, os ossos foram exumados e esmagados até que se tornaram um pó fino como talco. Depois disso, os homens saíram para caçar e pegaram todo tipo de caça. A carne desses animais foi misturada e cozida junto com os ossos em pó, e ingerida. Todos foram convidados e houve um grande festim comunal."
}

Antes de morrer, Pudicho Torres descreveu detalhadamente esses festins consecutivos para Richard e Susan Montag, um casal de missionários (Montag, Montag e Torres 1975). Segue-se um resumo dessa descrição. 
Quando um homem morria e os Huni Kuin não queriam deixar sua carne apodrecer, eles decidiam comê-la. Amarravam o corpo com cordas, na posição fetal, enquanto choravam. Enquanto isso, sua mulher o pranteava, dançando para a frente e para trás, falando com o cadáver. Ela nada comeria. Punham o corpo dentro de um grande pote, cobrindo-o com outro, antes de colocá-lo no fogo. Juntava-se grande quantidade de lenha, que era empilhada dentro da casa. Durante o velório acendiam o fogo. O corpo cozinhava até a aurora. Ninguém dormia, todos ficavam chorando até o sol aparecer. Então, retiravam a lenha que estava debaixo do pote e apagavam o fogo com água. Alguém varria o chão e todos cozinhavam bananas verdes para comer junto com o corpo.

Quando o céu clareava, o líder de cantos (chana xanen ibu) lhes dizia: "Vamos comer o corpo esfriado"; os homens formavam uma roda para dançar e, desta maneira, esfriar o corpo. O líder de cantos rezava pakadin para os participantes. Cantava: "frio, frio, frio; vamos comer" e, enquanto os participantes dançavam: "Comam, comam. O filho da anta que à noite morreu. Comam o filho da anta", e assim por diante.

O canto ordenava que eles comessem o filho da anta, misturando carne com legumes - milho, mandioca, inhame, amendoim, batatas-doces etc. Quando o canto e a dança terminavam, os parentes abriam o pote, tirando a tampa. O corpo era removido e colocado sobre uma esteira nova. Muitos homens se juntavam em volta do corpo e perguntavam: "Posso ficar com sua cabeça? Posso ficar com seu braço? Posso ficar com sua perna?" . Cada um pegava uma parte, separando-a com força. Tiravam bananas dos outros potes e comiam ali mesmo, em grupo.

Depois de comer, juntavam todos os ossos, quebravam o pote que servira de tampa, e empilhavam os cacos com os ossos. Estes eram queimados, usando-se a lenha que sobrara. Depois disso, o líder de cantos reunia todo o grupo para dançar pakadin novamente ... Então, ele cantava: "Camarão, guarde seu espírito, peixe carachama, guarde seu espírito, caranguejo, guarde seu espírito", enquanto os ossos do Nawa ("Estrangeiro"), do homem poderoso, do homem do céu, do jaguar, do jiadama (gigante), queimavam ao pé de uma árvore de madeira de lei.

Quando acabavam de dissociar seu nome dele mesmo fazendo pakadin, seu caminho de caça cobria-se de mato, suas urinas e fezes desintegravam-se, seu jardim desvinculava-se dele. Tudo isso feito, eles diziam ao seu gavião [tete, no caso um eufemismo para "espírito"]: "Você está indo embora. Você está se tornando um Xanen, um beija-flor. Quando encontrar o Inka, vá com ele. Vá para junto do xenipabu ["os velhos", os ancestrais]. Não volte para cá. Vá com eles. Jogue fora as contas do Inka. Jogue fora suas bando- 
leiras de sementes. Vá para o xenipabu". E o morto ia; aí, a dança parava.

Depois, a mulher do morto moía os ossos em sua "canoa", com pilão, socando até que sobrasse um pó bem fino. Ela punha um pouquinho do pó dentro de pequenas tigelas, e dava a cada um de seus parentes. Quando acabava a distribuição, o grupo de parentes dispersava-se, voltando, cada um, para seu lugar na maloca. No dia seguinte, o pó era moído mais uma vez, misturado com alimento vegetal e o líder ordenava: "Vão e matem caça para comer com os ossos misturados com vegetais". Então, os homens saíam para caçar todo tipo de animais. No dia seguinte, as mulheres cozinhavam beten, uma sopa grossa de vegetais, pó de osso e carne. Todos tomavam a sopa homens, mulheres e crianças.

Então, as mulheres choravam ao redor das "cinzas" (xanenen) do corpo até que terminassem, esquecendo o morto ${ }^{20}$. Era assim que eles comiam um corpo antigamente.

Pudicho fez também uma descrição mais sucinta do festim funerário de uma mulher:

Quando uma mulher morria, o marido cortava sua vagina, colocava dentro de um pequeno pote e fervia durante muito tempo, até amolecer. Ele a comia com bananas cozidas. Afastava-se para comer sozinho, não mostrava sua refeição para ninguém, embora as pessoas o seguissem. Ele comia as bordas da vagina e depois dava o restante da carne para os outros comerem. Eles comiam escondido e depois voltavam. O corpo estava fervendo dentro de um pote. O marido velava ao seu lado. Algumas noites depois, as chamas eram apagadas e as mulheres punham bananas para ferver.

Levantavam a tampa do pote e punham o corpo dentro de um cesto cargueiro trançado com padrão decorativo (kakan). Então, os homens dividiam a carne e todos comiam. Aí, juntavam os ossos e queimavam. Após esfriarem, eram esmagados e o pó distribuído e guardado à parte pelos participantes. Quando acabava a caçada, preparavam o beten e todos comiam os ossos misturados com carne de caça e vegetais, chorando enquanto engoliam. Depois de acabar o último pedaço, continuavam chorando até a aurora.

Lagrou (1991) colecionou outras descrições desses festins, principalmente as de Antônio Pinheiro, o qual confirmou muitos detalhes fornecidos por Pudicho e acrescentou outras informações importantes. A decisão de realizar um festim funerário era, por vezes, objeto de disputa. O líder podia decidir convocar esse funeral, mas a dona do pote poderia recusar ${ }^{21}$. Este era decorado com um desenho especial chamado kexin neya (Lagrou 1991). 
Lagrou esclareceu também um aspecto importante dos tipos de pakadin cantados enquanto o corpo fervia ou assava. Estes fazem referência à "seção" onomástica a que a pessoa pertencia. As "seções" referem-se a classes matrimoniais no interior das metades, determinadas pelo sistema onomástico de gerações alternadas (Kensinger 1984; 1995). Há quatro seções e oito subseções - quatro para mulheres e quatro para homens (D'Ans 1983; Kensinger 1995). Essas "seções matrimoniais" também funcionam como seções mortuárias, determinando as preces a serem cantadas e, depois, os tipos de animais que deverão ser caçados para o segundo festim. De acordo com Zé Augusto, essas preces pertencem à subcategoria das Kaxa Deve ("rezas para chorar"), conhecidas como Sain Inka Deve, para cantar antes de consumir o corpo com o objetivo de "esfriá-lo". Os cantos servem ao mesmo tempo para listar todos os nomes de animais específicos que os participantes do ritual de luto "desejam caçar e comer" e, conseqüentemente, para convocar os membros dessa espécie a se aproximarem do cantador. As preces de Sain Inka são, portanto, uma forma de magia de caça. Cada oração chama-se "Fazendo X - animal de caça". Na versão da oração "Fazendo anta" que coletei, o cantor chama as antas de Chai (cunhado, primo cruzado bilateral masculino) ${ }^{22}$.

Além de mecanismo classificatório de tipos de pessoas ou de cadáveres, as seções também apontam determinadas características corporais. Uma pessoa se parece de certo modo com o animal ao qual está ligada. Assim, ela é mais ou menos peluda, odorante, alta etc., dependendo da subseção de que faz parte. Os dados não são claros sobre a existência de outras semelhanças fundamentais ou relações entre o ser humano e sua contraparte animal.

As Sain Inka Deve desempenham, então, duas funções importantes e aparentemente relacionadas. Ademais de "esfriar o corpo", elas atraem o animal apropriado a fim de que possa ser caçado e consumido junto com os ossos do seu "companheiro humano" no segundo festim. A canção "fazendo a anta" atrai as antas, "fazendo o porco selvagem" atrai os porcos selvagens e assim por diante. A relação entre humanos e animais, construída discursivamente pela canção, é uma relação de afinidade masculina.

Por fim, obtivemos confirmação, junto a outras fontes, da prática de consumir os órgãos genitais de esposas e amantes. Eles eram cozidos em separado dentro de um pote simples de cerâmica (Lagrou 1991). Os membros genitais dos homens também eram consumidos, privadamente, por suas esposas e amantes, segundo Zé Augusto. Carvalho (1931) também informa sobre essa prática entre os Kaxinawá brasileiros. 


\section{Análise}

A estrutura do ritual parece ter sido praticamente idêntica para homens e mulheres, assim como é hoje o funeral. As diferenças eram de detalhes. Os homens eram deitados sobre uma esteira e as mulheres colocadas em uma cesta, mas suas carnes e ossos eram cozidos, distribuídos e consumidos de modo semelhante.

Parece razoável atribuir ao primeiro festim funerário a função de libertar a alma do corpo. Consumindo a carne, os parentes podiam talvez reter em si mesmos alguma coisa do morto, liberando sua alma para voar em direção à floresta. O endocanibalismo era ao mesmo tempo um ato de amor, de compaixão e de autoproteção (por causa da rápida libertação da alma do corpo). Como era possível desfazer-se de um corpo por outros meios, o ato de comê-lo era motivado, sobretudo, pelo amor e pelo parentesco - e não deve ser visto como predação. Ou seja, "outros", tais como feiticeiros, gente ruim, não-parentes, simplesmente não eram comidos.

Se a primeira metade do ritual (ferver, esfriar e consumir a carne humana) lidava com a alma do corpo, a segunda metade (assar, moer e consumir os ossos) lidava com a alma do olho. Depois de reacender o fogo, ordena-se a vários espíritos aquáticos que "guardem a alma". Assim realiza-se a dissociação dos outros aspectos mortais da pessoa. Ordena-se que o verdadeiro nome da pessoa seja desvinculado dos restos mortais do cadáver. Da mesma maneira, os vestígios dos feitos de uma pessoa na terra são destituídos de poder, porque separados de seu autor — os caminhos de caça de um homem, por exemplo, seus jardins, suas excreções corporais - , enquanto arde a pira funerária. O espírito do olho é, assim, libertado e despachado para sua viagem, enquanto as chamas se extinguem. O espírito é invocado pelo nome de "Gavião" e ordena-se que ele prossiga a viagem para a terra do Inka, no encontro dos ancestrais. Os ossos já não são humanos, mas estranhos, tratados como "Nawa, Jaguar, Homem do Céu". Ordena-se que o estrangeiro se desapegue dos poderes terrenos de origem celestial - o colar de contas do Inka. O consumo posterior dos ossos pode ser entendido como simbolizando a completa libertação da alma do olho. Passemos, então, a uma análise mais detalhada dos dois festins.

Denomino a primeira parte do rito de "festim da carne" e a segunda de "festim do osso". A análise baseia-se, fundamentalmente, no relato de Pudicho sobre o funeral de um homem. 


\section{O festim da carne}

\section{Primeira etapa: \\ Noite e Manhã/Cozimento e Esfriamento/Tornar Comestível e Tornar Ausente}

A noite torna-se aurora/dia.

Chorar torna-se cantar - desse modo os fluidos corporais (secreção e lágrimas) são substituídos por exalação "seca".

O luto estático de parentes indiferenciados, tanto homens como mulheres, é substituído pela dança dos homens em círculo.

O quente é esfriado (a carne por meio da canção; o fogo por meio da água e da retirada da lenha).

A carne humana não-comestível (crua) torna-se comestível (cozida, macia, fria).

A carne humana torna-se "caça" ou "peixe" cozidos.

"Semelhantes" terrestres tornam-se "outros" terrestres. (A alma do corpo desprende-se e se torna um espírito da floresta; só o corpo é animal; os verdadeiros animais de caça vêm para o local do funeral.)

O comedor de carne (o humano) torna-se o comedor de vegetais crus (animais de caça, peixe).

A presença transforma-se em ausência. (A alma do corpo parte e vai viver com os animais na floresta ou os peixes no rio.)

Dessa maneira, os temíveis vestígios da memória consciente são expulsos, o sofrimento do morto é aliviado e os laços de parentesco são reafirmados e, afinal, cortados de vez.

Essa primeira parte do rito, portanto, realiza duas transformações principais. Durante a noite, o corpo que cozinha no centro da casa é transformado em carne comestível, "macia". Esse é um cozimento especial, porque, normalmente, a carne só é cozida ligeiramente até que todos os vestígios de sangue tenham desaparecido. Só a mandioca é deixada a cozinhar por muitas horas, para que amacie. Vários informantes disseram que o cozimento de um corpo levava dias e noites, e não somente uma noite como é sugerido aqui. Além disso, os potes de cozer normalmente não trazem desenhos, enquanto o pote funerário é todo decorado. Esse pote tem uma tampa (um outro pote), de modo que a transformação se dá em um recipiente fechado. Se o vapor do cozimento é impedido de escapar, os parentes permitem que secreções escorram por suas faces. As lágrimas liberam a saudade e o pesar, retendo-se as "boas" qualidades do morto. Na etapa seguinte, a do esfriamento do corpo por meio do canto, ordena-se aos participantes do ritual que comam "o filho da anta", misturando a carne com vegetais postos para assar ao redor do pote funerário (Lagrou 1991). Em segui- 
da, a tampa é retirada e a alma do corpo é libertada e expulsa. Assim, além da transformação do não-comestível em comestível, realiza-se a transformação do que está dentro (a alma do corpo no interior do corpo; a pessoa na aldeia) no que está fora (a alma desliga-se da carne, a pessoa afasta-se da aldeia).

\section{Segunda etapa: \\ Meio-dia e Tarde/Distribuição e Consumo da Carne Humana/ Generalização e Retenção}

O externo torna-se interno (a carne do outro é consumida e digerida; a morte torna-se vida).

O particular torna-se geral (os restos públicos de uma pessoa são distribuídos entre todos, com exceção de suas partes íntimas que pertencem exclusivamente aos cônjuges e amantes).

Nessa etapa do festim da carne, o movimento primordial é o de retenção. O consumo da carne por todos retém as qualidades do morto no interior do corpo dos parentes consangüíneos e afins. Se a primeira expulsão da alma do corpo retira o que é temível e perigoso, que passa a ser despojado de memória, o consumo da carne retém o que é bom e que deve ser lembrado, como se fosse literalmente "incorporado". É como se o morto efetivamente fizesse um último ato constitutivo do parentesco. Em vez de oferecer carne de caça e peixe à comunidade, portanto, nutrir e cuidar de seus integrantes, ele oferece seu próprio corpo. O consumo do corpo é, de fato, constitutivo do parentesco. De modo semelhante, as partes íntimas do morto são oferecidas, em vida, aos cônjuges e amantes, "trabalhando", portanto, para fazer filhos e, conseqüentemente, o parentesco. Na morte, o consumo privado substitui a constituição reprodutiva do parentesco por uma constituição pela via do consumo.

O cônjuge ocupa um papel central no festim da carne. No caso do funeral de um homem, a esposa é a principal figura do ritual de luto, é ela que mói os ossos e distribui as cinzas entre as mulheres; ela é a primeira a comer o membro genital do marido. Os cônjuges consomem a parte do companheiro morto da qual têm maior conhecimento íntimo e com a qual podiam realizar o trabalho de procriação e reprodução. Essa parte do corpo não tem uma yuxin própria, além da alma do corpo. 


\section{O festim dos Ossos}

\section{Primeira etapa: \\ Assar os Ossos}

Ossos "crus" são queimados com cacos de cerâmica para ficarem rijos e quebradiços, esmagáveis na "canoa" como milho ou amendoim torrado.

O interno se torna externo (a verdadeira alma/alma do olho escapa voando como um Nawa).

Os vestígios do morto são extintos (o nome é dissociado, caminhos de caça são cobertos, fezes e urina desaparecem).

O terrestre passa a aquático (pede-se aos espíritos das águas que guardem a yuxin).

O terrestre se torna celeste (o espírito do olho escapa voando como um pássaro ou uma pessoa do céu).

O que é mutável se torna eterno.

O que tem nome se torna sem nome: aquilo que confere a uma pessoa a possibilidade de viver uma relação de parentesco (o nome) é desligado dos restos mortais da pessoa.

O antigo produtor perde apegos terrenos legítimos aos produtos do corpo (fezes, jardins, caminhos de caça e, sobretudo, os parentes).

Os verdadeiros afins masculinos passam a ser os afins celestiais.

Aquele que come carne e vegetais cozidos se torna um comedor de carne crua (gavião, jaguar, Inka).

\section{Segunda etapa:}

\section{Esmagar, Distribuir, Matar, Esmagar Novamente, Consumir}

Ossos humanos assados (rijos) são esmagados para se tornarem pó, como se fossem vegetais.

Um produto específico é distribuído a todos (o pó dos ossos da esposa a outras mulheres).

O pó dos ossos humanos se torna vegetal. (As mulheres moem de novo o pó junto com vegetais para fazer a sopa.)

Mata-se o "companheiro animal" do morto.

Os estrangeiros são trazidos para dentro (as presas são trazidas para a aldeia).

Caça e peixe, vivos, se tornam alimento.

Os lembrados são "esquecidos" (por intermédio da refeição e da sessão final do ritual do luto). 
Como ocorreu na primeira parte do festim da carne, o processo de separação e expulsão de dentro para fora, caracteriza a primeira etapa do festim dos ossos. Na segunda parte, porém, o principal processo não é o de retenção, mas de nulificação e extinção. Mais uma vez, a ingestão do banquete constitui o parentesco. No primeiro, o festim da carne, o alimento é sólido; no segundo, o festim dos ossos, é um líquido grosso, a sopa. Há uma inversão da associação tripartite entre humano-animalvegetal nos dois festins. Durante o primeiro, o humano consumido está associado ao animal e oposto ao vegetal; no segundo, o humano consumido está associado ao vegetal e oposto ao animal. Se a natureza animal da carne humana consumida é basicamente metafórica (afinal de contas, trata-se realmente de carne humana), pode-se dizer que a natureza vegetal dos ossos consumidos é metonímica - por seu processamento na "canoa" e seu disfarce na massa vegetal, que é misturada com a sopa de carne e vegetal. Portanto, o primeiro festim faz dos participantes comedores daqueles animais que se alimentam de vegetal (porco selvagem, anta, arara). Esta caça metafórica é ingerida misturada a vegetais de verdade. O segundo festim torna seus participantes comedores de substância vegetal misturada com verdadeiros peixes e animais vegetarianos. Por meio das atividades de expulsão anteriores aos festins, e que ocorrem durante a fervura ou cozimento, assim como nos ritos do luto, da dança e do canto, os participantes destituem o morto de sua natureza de comedor de carne. Ou, para ser mais exata, dissociam seus restos mortais da prática de comer carne, seja na forma do cozido, como um ser humano, seja na forma do cru, como um yuxibu (monstro/deus). Já que os xamãs, após a morte, se transformam nesses yuxibu - cobras e jaguares - , eles têm de ser queimados em vez de comidos. Consumi-los seria destruir a comunidade humana, porque isso levaria necessariamente a que os consumidores de carne cozida passassem a ser consumidores dos animais que comem carne crua, e assim, por associação, consumidores de canibais como os Inkas, que gostam de comer cru seus "outros", os humanos. Os humanos não são nem canibais nem consumidores de carne crua. Ser canibal significa ser outro - Inka ou yuxibu —, tudo o que os Kaxinawá vivos se esforçam por não ser. Ainda assim, é destino dos mortos irem para junto do Inka e se tornarem integrantes de seu povo por meio de uma pura, eterna e improdutiva afinidade. 


\section{Conclusão}

Talvez seja melhor deixar, definitivamente, de rotular os ritos funerários kaxinawá, anteriores ao contato, como "canibalismo", tendo em vista os aspectos simbólicos envolvidos. Embora os participantes dos festins efetivamente consumissem carne e ossos humanos, eles simultaneamente se distanciavam do ato transformando os restos mortais em substância animal ou vegetal comestível. Em conseqüência disso, a alma do olho, que se torna imortal, é capaz de transformar-se em um deus do céu, uma aliada dos verdadeiros canibais, os Inkas, e dos autênticos consumidores de carne crua, os jaguares, os gaviões e os urubus. Ainda assim, porém, nem tudo é o que parece. Quando a verdadeira alma chega aos céus, ela não é consumida pelos deuses - na verdade, o consumo da alma pelos yuxibu é um desastre, como vimos antes: causa a extinção e não a imortalidade. Ao contrário, quando a alma do corpo chega aos céus, ela recebe um convite para comer vegetais, especialmente, amendoins, por meio de um canto entoado por Kana (o Trovão) e Uxe (a Lua) (Lagrou 1991). Pode-se ver e ouvir esse canto, na terra, na forma do trovão e do relâmpago que assinalam a chegada da verdadeira alma na aldeia do céu.

O convite para comer amendoins poderia ser interpretado como o convite para o início do processo de tornar-se um deus do céu. Para os Kaxinawá, dar de comer é uma forma de constituir o parentesco em um sentido material (McCallum 1989). Ao "comer" os amendoins, a alma do olho começa a tornar-se parente dos Inkas. (Como se diz que os mortos nem comem nem têm relações sexuais, só consigo explicar essa incoerência sugerindo que o consumo não é real, mas metafórico.) Mas por que exatamente amendoins? Possivelmente pela associação entre os amendoins, a lua e a fertilidade. Os amendoins são plantados nas margens dos rios, no início da estação seca, por ocasião da Lua Nova. As sementes são deixadas de molho para brotar e, na noite anterior ao plantio, realiza-se um ritual especial denominado "chamando/nomeando os amendoins" (tama kenakinan). Por toda a aldeia, meninos batem o pilão contra as "canoas" de triturar. O barulho forte produzido assemelha-se ao do trovão. "Denkainkani", "Está trovejando", dizem as pessoas, rindo. É como se Kana fosse tão responsável pela fertilidade dos amendoins quanto Uxe é responsável pela fertilidade das mulheres. Seja como for, por que as almas dos mortos seriam convidadas a comer os amendoins? Talvez porque ele é o alimento especial de Kana. Já que ele é o principal líder da aldeia do céu, seria bem apropriado que ele convidasse as novas almas a comer. Mas também é possível que o convite se deva à associação do tro- 
vão com o plantio dos amendoins, que significa uma "revivificação". Na terra, é a transformação das sementes duras e secas (bedu) em novas plantas; no céu, é a transformação do bedu yuxin endurecido (assado na pira funeral) em yuxin kuin e, portanto, em deuses do céu.

O consumo de alimentos vegetais misturados com carne ou peixe constrói o corpo kaxinawá. As pessoas são, em grande parte, aquilo que comem e as restrições alimentares em casos de doença, gravidez e couvade, por exemplo, refletem essa concepção (Kensinger 1981; 1989; 1995; McCallum 1989; 1996). Também aqui o gênero é importante. Quando as pessoas retomam a ingestão de carne, após um período de observação de restrições alimentares, elas devem começar comendo "carne de caça" fêmea, antes de passar às carnes mais perigosas de animais machos. $\mathrm{O}$ consumo é a forma privilegiada de transformação do corpo. Assim, os humanos transformam animais e vegetais em carne e ossos humanos, da mesma maneira que faziam com os corpos de determinados parentes mortos.

Para bem compreender o pensamento kaxinawá sobre a morte e o processo de morrer, parece-me essencial correlacioná-lo com sua concepção do consumo. A morte é um processo de transformação em série que inclui a possibilidade de ser consumido em uma etapa e de consumir os amendoins de Kana em uma etapa final. Os antigos ritos endocanibais podem ser vistos como a contrapartida, e a inversão, da necessidade exocanibal dos Araweté de serem comidos pelos deuses para se transformarem eles próprios em deuses. Os Kaxinawá tornaram-se deuses, primordialmente, pelo poder de consumo humano em vez do consumo celestial. Em lugar de os humanos dependerem da intervenção canibal dos deuses para se tornarem deuses, estes é que dependem dos humanos para lhes proporcionar "parentes" por meio do canibalismo terrestre.

Os ritos endocanibais foram abandonados ${ }^{23}$. Não eram mais necessários, nem para aliviar o sofrimento dos vivos, nem para facilitar a travessia dos mortos para o céu. Pudicho Torres foi cantado, possivelmente, teve um enterro cristão, no estilo que testemunhei, e, por fim, convocouse um chidin para ele. Isso foi suficiente para encerrar o processo da morte e para que ele se tornasse imortal. Mas, apesar do abandono dos ritos, deve estar claro agora que existem muitas continuidades entre as práticas mortuárias do passado e do presente e os conceitos que as sustentam. O panteão cristão, especialmente, é associado ao panteão xenipabu - como Inka é associado a Deus e a Lua a Jesus Cristo. O "céu" (nai) é sinônimo de paraíso. Essas inovações não são tidas como negação do conhecimento tradicional, mas como um aperfeiçoamento. Há bastante espaço entre os Kaxinawá para divergências de opinião em torno de 
um grande número de práticas e detalhes. Alguns "crentes" se recusam a tomar a bebida alucinógena nixi pae, dizendo que é coisa do diabo. Mas todos concordam que os ritos funerários endocanibais não têm mais lugar na vida kaxinawá contemporânea.

Já foi sugerido que a concepção da morte entre as culturas das Terras Baixas da América do Sul é uma questão principalmente de predação ${ }^{24}$. Este artigo deixa claro que tal conclusão não é aplicável ao caso kaxinawá. A ação predatória por parte de inimigos/estrangeiros - Nawa - causa a morte de homens, mas não a de mulheres. Este é apenas um momento do processo de morrer. Antes dele, uma outra ação, causada pela intervenção de outrem, para envenenar e enfeitiçar um homem, provoca a doença que leva ao aparecimento do Nawa. Quando o homem morre, os Inkas conduzem-no, em festa, até o céu - a terceira transformação da série. A atividade da alma do morto, "comendo" os amendoins de Kana e da Lua, realiza a quarta e última transformação. A alma do morto encontra-se pronta para "desposar uma mulher Inka" - não para ter relações sexuais com ela, ou para formar uma parceria de produção e reprodução (este é um privilégio e um ônus dos que vivem), mas como um parente por afinidade do Inka. Para os homens essa série de transformações representa uma progressão do estado de estrangeiro do estrangeiro [outsider's outsider] (a presa de Nawa, afim masculino do Inka) para ser um igual ao estrangeiro (parente de Kana, marido de sua irmã). Para as mulheres, a progressão segue uma trajetória diferente. Se os homens são estrangeiros do estrangeiro [the outsider's outsider], as mulheres são os íntimos do estrangeiro [the outsider's insider] — sua transformação em deuses do céu é mediada pelo parentesco e não pela hostilidade e/ou afinidade masculina. Isso explicaria o controle exclusivamente feminino do "verdadeiro grafismo" (kene kuin, um signo dos Inkas pintados e do caminho do Inka), sua relação especial com a Lua e a fertilidade lunar, sua habilidade para criar/transformar ( $b a$-) o alimento cru em cozido, o sêmen cru em bebês. Em certo sentido, quando os homens morrem, fazem sua jornada final para o desconhecido; quando as mulheres morrem, elas vão para casa.

Tradução: Vera Pereira

Revisão da autora
Recebido em 1 de junho de 1995

Aprovado em 21 de outubro de 1995

Cecilia McCallum é pesquisadora-associada do Departamento de Antropologia Social da London School of Economics. 


\section{Notas}

* Este artigo é uma versão modificada de um paper, apresentado in ausentia no 47을 Congresso Internacional dos Americanistas (New Orleans, 1991), baseado em pesquisa de campo realizada entre 1983 e 1985, no Brasil, com financiamento do ESRC (Grã-Bretanha), e em 1990, com financiamento da Leverhulme Foundation. Agradeço a ambas instituições, bem como a K. Kensinger, E. Viveiros de Castro e R. Montag. Meu maior débito é para com meus professores ("informantes") Kaxinawá, mencionados no próprio texto.

1 Não há nenhum padrão ortográfico para a língua kaxinawá. Adotei o mais familiar para mim, que é o usado pelos Kaxinawá do Peru e pelos Kaxinawá brasileiros que estudaram em escolas peruanas. Ver Montag (1981).

2 Entre outras coisas, porque sintetiza ou põe em relevo aspectos essenciais de importantes estudos anteriores, como, por exemplo, os de Carneiro da Cunha (1978) e Albert (1985).

3 Estudos realizados por alunos e colegas de Viveiros de Castro aprofundaram, de modo crítico, muitos argumentos formulados pelo autor, à luz de etnografias densas e originais: por exemplo, Vilaça (1990; 1992; 1993); e Gonçalves (1993). Por ocasião de um seminário sobre a concepção da morte na região das Terras Baixas sul-americanas, realizado em Oxford, em 1989, idéias centrais de Viveiros de Castro, tais como a de que a morte é principalmente um assunto de predação, foram discutidas.

4 Ver também Overing (1993) e Descola (1993) para uma análise crítica da "economia simbólica da predação".

5 Não quero sugerir que esses grupos lingüísticos tenham uma "cultura" comum. Tais categorias, como "Pano" e "Tupi", devem ser entendidas como constructos analíticos.

6 Kensinger, o primeiro etnógrafo moderno dos Kaxinawá peruanos, publicou numerosos e importantes artigos acerca de vários aspectos da vida desse grupo nos últimos 25 anos. A maioria desses estudos foi atualizada e republicada em uma nova coleção (Kensinger 1995).

7 Tenho consciência das dificuldades inerentes à tradução de um conceito complexo como yuxin por "alma" ou "espírito", mas preferi seguir os próprios Kaxinawá, que utilizam esses termos em português.

8 Entretanto, uma fonte, pelo menos, sugere que a sombra de um feiticeiro pode se desligar e vaguear durante a noite, ferindo as pessoas (Capistrano de Abreu 1941:403-435). 
9 A respeito do xamanismo, da cura e da feitiçaria kaxinawá, ver Kensinger $(1974 ;$ 1995); McCallum (1996); e Lagrou (1991).

${ }^{10}$ Sobre o papel dos Inkas na mitologia e na história kaxinawá, ver McCallum (previsto a). Estas figuras estão presentes na mitologia Pano. Ver, por exemplo, Melatti $(1985 ; 1989)$.

11 Sobre a medicina kaxinawá, ver Kensinger (1974; 1995); Lagrou (1991); e McCallum (1996).

12 Não analiso a morte e o enterro de crianças. São ocasiões mais particulares e tratadas de modo menos formal.

13 Kensinger (1995) afirma que nunca viu ninguém derramando lágrimas durante os oito funerais a que assistiu. Não tenho recordações seguras sobre isso, de modo que apenas observo que posso estar errada. Kensinger viveu entre os Kaxinawá do Peru de meados dos anos 50 até o final da década de 60. Alguns deles são parentes próximos dos Kaxinawá brasileiros que estudei. É possível, porém, que alguns detalhes do ritual de luto tenham mudado, como o uso da secreção nasal. Kensinger observou que o fluxo de secreção nasal era cuidadosamente deposto sobre o cadáver. Embora muitas pessoas tenham afirmado que "era para lavar o morto, em uma expressão física da dor que sentiam" (Kensinger 1995:234), alguns de seus melhores informantes afirmaram que a razão era fazer sair o espírito do corpo e evitar seu reaparecimento.

14 Essas "Canções para Despedir a Alma" são analisadas mais detalhadamente em McCallum (1996).

15 Lagrou confirma essa observação, sugerindo que isso se deve ao fato de que a verdadeira alma deve, em primeiro lugar, viajar rio abaixo para subir ao céu pela escadaria gigante na foz do rio. Outros informantes me confirmaram que efetivamente a alma podia descer o rio.

16 Deshayes e Keifenheim (1982:240-249). Grompes continuava a ser líder em 1996, como era na época da pesquisa de campo.

17 Ver também D'Ans $(1975 ; 1991)$.

18 Townsley (1988) analisa o destino das almas do olho entre os Yaminawá (weroyoshi). O arco-íris, chamado de Nawa Wai ou de Yushinawa Wai, representa para eles um caminho para bai iri (terra inundada), o domínio dos mortos, localizado embaixo da terra. A chuva é o veículo das almas para alcançar esse território e o arco-íris assinala sua passagem. A respeito do mito de origem do arco-íris, 
ver Capistrano de Abreu (1941).

19 O complexo ritual e os cantos, longos e extremamente ricos, do chidin estão ainda por ser adequadamente descritos e analisados. Algumas descrições e sugestões analíticas encontram-se em McCallum (1989). A maioria dos estudiosos dos Kaxinawá faz referência a chidin. Chamo a atenção para o fato de que a associação com a criação e a vida também aparece em outro contexto, o de dar à luz uma criança, quando canções específicas de chidin são usadas. Mas este é um tema que merece outro artigo.

${ }^{20}$ Chamo a atenção para a semelhança entre o termo que indica as cinzas mortuárias - xanenen - e outros termos associados com o processo de morrer xane pinu (xane beija-flor, uma metáfora para olho da alma); xanen tapiti (a escadaria que leva aos céus). Xane (uma espécie de cobra) e xanen ibu (líder) são outros termos que indicam poder. Não sei se essas associações e semelhanças têm um significado.

${ }^{21}$ Não se sabe qual precaução ritual ela deveria tomar quando seu pote era usado. Como o festim deveria ser realizado imediatamente após a morte, o pote tinha de estar sempre pronto para ser utilizado. É possível que a falta desse pote especial, ou a recusa em emprestá-lo, explique o processo alternativo de assar o corpo da pessoa com um pote em cima da cabeça, como presenciou Sombra (1913), em 1906.

22 Zé Augusto listou as seguintes: Inani (a metade Onça, parte feminina) tinha Ava Xanu Va- (Fazendo anta) e Ava Isa Va- (Fazendo anta pássaro); Inu (a metade Onça, parte masculina) tinha Ava Buaibu (Antas chegando) e Kanava(Fazendo arara azul); Banu (a metade Resplendor, parte feminina) tinha Chana Yava Va- (Fazendo porco selvagem); Dua (a metade Resplendor, parte masculina) tinha Tsatsava- (uma espécie de peixe), Bina (uma vespa), Yava (porco selvagem). Esses dados fornecidos pelo informante coincidem em parte com os de Lagrou (1991), que acrescenta ainda: Isava- (pássaro) para Dua e também Dunu (cobra), mas observa que é perigosíssimo cantar o pakadin da cobra. Kensinger (1984; 1995) afirma que as seções matrimoniais são: para Dua/Banu, Yava e Dunu; para Inu/Inani, Ava e Kana. Quer dizer, em grande parte, os dados coincidem, embora cada gênero de subseção esteja ligado a três ou quatro espécies adicionais, segundo os dados mais recentes. Desconfio que a razão do aparecimento dessas outras espécies é que nomes alternativos foram usados para indicar a espécie-alvo. Agora, é evidente que o texto de Pudicho Torres menciona um homem da metade Inu, seção Anta.

${ }^{23}$ Kensinger (1995) cita um informante que lhe explicou que o canibalismo foi abandonado no Peru por causa de uma epidemia. Em 1951, quatro quintos da população adulta morreram em menos de um mês. "'Havia tantos cadáveres', respondeu o chefe Awadetsati, esfregando os olhos com as mãos, como se quisesse afastar essa lembrança. 'Todo meu povo estava doente, muitos estavam morrendo. Ninguém tinha coragem de desfazer-se dos corpos. Algumas pessoas agoni- 
zando, arrastavam-se para fora da aldeia para que o cheiro de decomposição de seus corpos não incomodasse os doentes'. Depois de dizer essas palavras, ele levantou-se da rede e deu por terminada nossa conversa" (Kensinger 1995:231).

${ }^{24}$ Essa sugestão de Viveiros de Castro foi discutida no seminário sobre a concepção da morte na América do Sul e Central, realizado em Oxford, em 1989. Vilaça $(1990 ; 1992 ; 1993)$ analisa a relação entre afinidade, hostilidade, predação e canibalismo funerário entre os Wari' (Pakaas Novas). Ver Viveiros de Castro (1989; 1992a; 1992b; 1993) para uma discussão mais geral da relação entre afinidade e canibalismo nas Terras Baixas sul-americanas.

\section{Referências bibliográficas}

ALBERT, Bruce. 1985. Temps du Sang, Temps des Cendres. Représentations de la Maladie, Système Rituel et Espace Politique chez les Yanomami du Sud-Est (Amazonie Brésilienne). Thèse de Doctorat, Université de Paris X, Nanterre.

BELAÚNDE, Elvira. 1992. Gender, Commensality and Community among the Airo-Pai of West Amazonia (Secoya, Western-Tukanoan Speaking). Ph.D. Thesis, London University.

CAPISTRANO DE ABREU, João. 1941 [1914]. Rã-txa hu-ni ku-i: Gramática, Textos e Vocabulário Caxinauás. Rio de Janeiro: Edição da Sociedade Capistrano de Abreu.

CARNEIRO DA CUNHA, Manuela. 1978. Os Mortos e os Outros: Uma Análise do Sistema Funerário e da Noção da Pessoa entre os Índios Krahó. São Paulo: Hucitec.

CARVAlHO, J. B. 1931. “Breve Notícia sobre os Indígenas que Habitam a Fronteira do Brasil com o Peru". Boletim de Museu Nacional, 7(3):225-256. D'ANS, André-Marcel. 1975. La Ver- dadera Biblia de los Cashinahua. Lima: Mosca Azul. . 1983. "Parentesco y Nombre: Semántica de las Denominaciones Interpersonales Cashinahua (Pano)" . In: A. Corbera (ed.), Educación y Linguística en la Amazonia Peruana. Lima: CAAAP. . 1991. Le Dit des Vrais Hommes. France: Gallimard.

DESCOLA, Philippe. 1993. "Les Affinités Sélectives: Alliance, Guerre et Prédation dans l'Ensemble Jivaro". L'Homme 126-128, XXXIII (2-4):171-190.

DESHAYES, Patrick e KEIFENHEIM, Barbara. 1982. La Conception de l'Autre chez les Kashinawa. Université de Paris. mimeo.

DOLE, Gertrude. 1974. "Endocannibalism among the Amahuaca Indians". In: P.J. Lyon (ed.), Native South Americans: Ethnology of the Least Known Continent. Prospect Heights: Waveland Press. pp. 302-308.

ERIKSON, Philippe. 1986. "Alterité, Tatouage et Antropophagie chez les Pano: Le Belliquee Quête de Soi". 
Journal de la Société des Americanistes, LXXII:185-209.

GONÇALVES, Marco Antonio. 1993. O

Significado do Nome: Cosmologia e Nominação entre os Pirahã. Rio de Janeiro: Sette Letras.

GOW, Peter. 1989. "The Perverse Child:

Desire in a Native Amazonian Subsistence Economy". Man, 24:299314.

.1991. Of Mixed Blood: Kinship and History in Peruvian Amazonia. Oxford: Clarendon.

KENSINGER, Kenneth. 1973. "Banisteriopsis Usage among the Peruvian Cashinahua". In: M. Harner (ed.), Hallucinogens ans Shamanism. Oxford: Oxford University Press.

. 1974. "Cashinahua Medicine and Medicine Men". In: P.J. Lyon (ed.), Native South Americans: Ethnology of the Least Known Continent. Prospect Heights: Waveland Press. . 1981. "Food Taboos as Markers of Age Categories in Cashinahua Society". WPSAI, 3:157-172.

. 1984. "An Emic Model of Cashinahua Marriage". In: K. Kensinger (ed.), Marriage Practices in Lowland South America. Urbana \& Chicago: University of Illinois Press. pp. 221251.

. 1989. "Hunting and Male Domination in Cashinahua Society". In: S. Kent (ed.), Farmers as Hunters: The Implications of Sedentism. Cambridge: Cambridge University Press. pp. 18-26.

. 1991. "Feathers Make us Beautiful: The Meaning of Cashinahua Feather Headresses". In: R. Reina e K.Kensinger (eds.), The Gift of Birds: Featherwork of Native South American People. Philadelphia: University Museum Publication. pp. 40-49. . 1992. "A Body of Knowledge, or, the Body Knows". In: Expedition.
Philadelphia: University Museum Publication.

.1995. How Real People Ought to Live: The Cashinahua of Eastern Peru. Prospect Heights: Waveland Press.

LAGROU, Elsje. 1991. Uma Etnografia da Cultura Kaxinawá: Entre a Cobra e o Inca. Dissertação de Mestrado, Universidade de Florianópolis.

MCCALLUM, Cecilia. 1989. Gender, Personhood and Social Organization among the Cashinahua of Western Amazonia. Ph.D. Thesis, London School of Economics.

.1990. "Language, Kinship and Politics in Amazonia". Man, 25:412433.

1994. To Be an Indian in Brazil, to Be a White in Acre: Inter-Ethnic Relations in Contemporary Amazonia. Comunicação apresentada na XIX Reunião da ABA, Niterói, RJ, 27-30 de março.

- (1996). "The Body that Knows: From Cashinahua Epistemology to a Medical Anthropology of Lowland South America". Medical Anthropology Quarterly, 10(3):1-26.

_ . (previsto a). "Os Incas e os Nawas: Produção, Transformação e Transcendência na História Kaxinauá". In: B. Albert e A. Ramos (eds.), Pacificando o Branco: Cosmologia, História e Política do Contato no Norte da Amazônia. Brasília/Paris: ORSTOM. . (previsto b). "The Acquisition of Gender and the Skills of Production: The Cashinahua Case". Cadernos PAGU.

MELATTI, J.C. 1985. "A Origem dos Brancos no Mito Shoma Wetsa". Anuário Antropológico/84. Rio de Janeiro: Tempo Brasileiro.

. 1989. "Shoma Wetsa: A História de um Mito". Ciência Hoje, 53:56-31. MONTAG, R., MONTAG, S. e TORRES, P. 
1975. "Endocanibalismo Fúnebre de los Cashinahua. Datos Etnolingüústicos, 45. Yarinacocha, Peru: ILV.

MONTAG, S. 1981. Diccionario Cashinahua. Yarinacocha, Peru: MEP/ILV. 2 vols.

OVERING, J. 1986. "Images of Cannibalism, Death and Domination in a 'Non-Violent Society' ". In: D. Riches (ed.), The Anthropology of Violence. Oxford: Basil Blackwell.

.1989. "The Aesthetics of Production: The Sense of Community among the Cubeo and Piaroa". Dialectical Anthropology, 14:159175.

. 1991. "A Estética da Produção: O Senso de Comunidade entre os $\mathrm{Cu}$ beo e os Piaroa". Revista de Antropologia, 34:7-33.

.1993. "Death and the Loss of Civilized Predation among the Piaroa of the Orinoco Basin". L'Homme 126128, XXXIII (2-4):191-211.

RIVIÈRE, Peter. 1993. "The Amerindianization of Descent and Affinity". L'Homme 126-128, XXXIII (2-4): 507 516.

SOMBRA, Luis. 1913. "Os Kaxinauás: Breves Notas sobre seus Modos e Costumes". Jornal do Comércio, Rio de Janeiro, 11 de janeiro.

TOWNSLEY, Graham. 1988. Ideas of Order and Patterns of Change in Yaminahua Society. Ph.D. Thesis, Cambridge University.

VILAÇA, Aparecida. 1990. "O Canibalismo Funerário Pakaa Nova: Uma Etnografia". Comunicação, 19, PPGAS/ MN/UFRJ. .1992. Comendo como Gente: Formas do Canibalismo Wari' (Pakaa Nova). Rio de Janeiro: Anpocs/Editora UFRJ.

.1993. "O Canibalismo Funerário Pakaa-Nova: Uma Etnografia". In: E. Viveiros de Castro e M. Carneiro da Cunha (orgs.), Amazônia: Etnologia e História Indígena. São Paulo: NHII/USP/FAPESP. pp. 285-310.

VIVEIROS DE CASTRO, E. 1986. Araweté: Os Deuses Canibais. Rio de Janeiro: Jorge Zahar Editores/Anpocs. .1989. Modelos Dravidianos na Amazônia: Um Programa de Investigação. mimeo. .1992a. From the Enemy's Point-ofView. Chicago: Chicago University Press. . 1992b. "Apresentação". In: A. Vilaça, Comendo como Gente: Formas do Canibalismo Wari' (Pakaa Nova). Rio de Janeiro: Anpocs/Editora UFRJ. pp. XI-XXIII.

.1993. "Alguns Aspectos da Afinidade no Dravidianato Amazônico". In: E. Viveiros de Castro e M. Carneiro da Cunha (orgs.), Amazônia: Etnologia e História Indígena. São Paulo: NHII/USP/FAPESP. pp. 149-210. 
Resumo

Este artigo apresenta uma etnografia do pensamento e das práticas relativos à morte, ao processo de morrer e à condição de pessoa entre os Kaxinawá (Huni Kuin) da Amazônia Ocidental (Brasil e Peru Oriental). Articula o simbolismo de gênero, resultante das práticas cotidianas, com a forma das relações sociais estabelecidas entre a pessoa agonizante e os espíritos terrestres, aquáticos e celestiais em cada etapa do processo de morrer. A etnografia visa fornecer um contraponto crítico ao modelo que trata dessas mesmas relações e de seus processos, conhecido nos estudos americanistas como "economia simbólica da predação", no qual a "troca" funciona ao mesmo tempo como processo básico e como metáfora. O artigo sugere que uma análise da morte entre os Kaxinawá deve enfatizar o ciclo inteiro da produção consumptiva e não apenas o simbolismo da predação e da troca.

\section{Abstract}

This article is an ethnography of thinking and practice about death, the process of dying and personhood among the Cashinahua (Huni Kuin) of Western Amazonia (Brazil and Eastern Peru). It relates gender symbolism, arising from the practice of daily life, to the form that social relations between the moribund person and terrestrial, aquatic and celestial spirits take during each stage of dying. This ethnography is provided as a critical counterpoint to the model of such relations and the processes that surround them known in Americanist studies as "the symbolic economy of predation", in which "exchange" functions as the key process and metaphor. The paper suggests that any analysis of death among the Cashinahua must place emphasis on the whole cycle of consumptive production, not just on the symbolism of predation and exchange. 